International Research Journal of Management, IT \& Social Sciences
Available online at https://sloap.org/journals/index.php/irjmis/
Vol. 6 No. 5, September 2019, pages: 210 217
ISSN: 2395-7492
https://doi.org/10.21744/irjmis.v6n5.728

\title{
Market Reaction as an Impact of Announcement Increase Fed Interest Rate in Asian and European Area
}

\author{
Ni Made Indah Mentari ${ }^{a}$ \\ Luh Gede Sri Artini ${ }^{\text {b }}$
}

Article history:

Received: 27 March 2019

Accepted: 31 July 2019

Published: 03 September 2019

Keywords:

abnormal;

efficiency;

event study;

market;

return;

\begin{abstract}
The purpose of this study is to determine whether there is a difference in the average abnormal return around the date of the announcement of the Fed's interest rate hike in Asia and the European region. The sample of this study was 18 emerging market countries' index indices in Asia and Europe with sample collection techniques using purposive sampling. This study uses One Way Anova analysis techniques and One Sample T-test. The results found that there was no difference in the average abnormal return before and after the announcement of the Fed's interest rate increase. This condition shows that markets in the two regions do not react significantly because markets in Asia and the European region are in an efficient condition in the form of half strong, where the market absorbs information quickly and is reflected in stock prices so there is no difference in the average abnormal return in both regions. The absence of a difference in the average abnormal return is also caused by the uncertainty of the global economy making investors more careful in making investment decisions.
\end{abstract}

2395-7492@ Copyright 2019. The Author. This is an open-access article under the CC BY-SA license (https://creativecommons.org/licenses/by-sa/4.0/) All rights reserved.

\section{Author correspondence:}

Ni Made Indah Mentari,

Faculty of Economics and Business, Udayana University, Denpasar, Indonesia.

Email address: indahmentari08@gmail.com

\section{Introduction}

The improved condition of the United States economy makes the Fed more confident raising interest rates. On June 13, 2018, the Fed raised interest rates by 25 bps to $2 \%$. The impact of this event is the number of foreign investors who attract investment from certain countries to the United States.

Rising US interest rates affect the global economy. Due to a large number of investors transferring investment to the United States, the demand for US dollars (USD) is higher so that currencies in a number of countries have depreciated. The depreciation of a country's currency can affect the economic side, especially export-import activities that require US dollars (USD) as its currency. This exchange rate condition will certainly have an impact on the

\footnotetext{
a Udayana University, Denpasar, Indonesia

${ }^{\mathrm{b}}$ Udayana University, Denpasar, Indonesia
} 
company's operations which will affect the company's revenue and ultimately will affect the profits to be received by shareholders.

Investors who invest their funds in the capital market will see this event as the information received by the market. Based on the concept of an efficient market, in the market there is a process where prices go to equilibrium in response to information from an event that enters the market so that stock prices can be undervalued or overvalue when the market reacts to information.

In the capital market, the price of shares in that market can be seen from the stock index. An event that contains information will affect the stock price that can be seen with the presence or absence of abnormal returns. Abnormal return is the difference between expected return and realized return. Wardhani (2012), t-test calculations show that there is a significant positive abnormal return on several days around the event date, which means the market responds to this event as good news.

Whether or not a market reaction occurs as a result of the Fed's interest rate hike can be seen from the abnormal return around the event date. Abnormal returns around the event date can affect the stock price. Abnormal returns that occur around the event date are considered a signal by investors that the Fed's interest rate hike policy events will have both positive and negative effects on the economies of the countries in the world and will be more profitable if investing in the United States.

According to Young \& Bacon (2012), in his research found a significant positive market reaction before the announcement of the decline and around the day of the announcement. The results of other empirical analyses show that the prices of the largest companies' shares reacted in the first minute after the news release. The WSE index reacts similarly to good and bad news about the US economy (Gurgul \& Wójtowicz, 2014).

Specifically, for this study, the announcement of a FED fund interest rate cut was seen as a positive signal by bank stock investors who believed that a lower interest rate would initiate the desired expansive economic activity. Not all countries in the world are affected by the Fed's policy because every country has different economic conditions. In addition, the results of previous studies indicate that some types of announcements depend on the country because the same type of action has different effects depending on the state of the crisis (Grace et al., 2017).

\section{Literature Review and Hypotheses}

The market reaction that arises due to an event indicates that the market is efficient in the form of half strong. Efficient half-strong form is used to test the information content in an event (event studies) (Tandelilin, 2010; Kusuma \& Yasa, 2019).

The announcement of the Fed's interest rate hike on June 13, 2018, can be a signal and information for investors around the world. This information causes a market reaction that can be seen from the presence or abnormal return around the announcement. An abnormal return around the announcement date indicates the market reacts to the event.

In a study conducted by Tsai \& Chen (2018), about the market reaction to changes in oil prices in Taiwan, found a significant positive abnormal return. The decline in oil prices for transportation companies is considered good news. As a result, in the days of falling oil prices, investors took an optimistic attitude and followed the actions of other investors to create a herding effect. Significant positive abnormal returns also occur in airlines and containers. The same research results show a significant stock price reaction to the events of uncertain government policy regarding major uranium (Ferguson \& Lam, 2016; Aggarwal, 2017).

Announcements or events that have a major influence on the economy such as monetary policy will have an effect on all aspects including the capital market. Empirical research by Abdioglu \& Aytekin (2016), shows that the Monetary Policy Committee's decision for 2008 as a year of global financial crisis and 2012 as another year (and the year in which new monetary policy rules are applied) has an impact on the share price of Turkish bank deposits registered in Bursa Bursa.

The same research results revealed by Fausch \& Sigonius (2017) about the impact of monetary policy on stock prices provide empirical evidence that unconventional monetary policy has a significant impact on stock returns. Future dividends are identified as the main propagation channel of unconventional monetary policy on the observed stock market response. Policies made by the Fed can not only affect the country itself, namely the United States. However, other countries, especially those that have political and economic relations with America can also be affected.

Wang \& Zhu (2013), study, shows the results that international stock return co-movement plays an important role in explaining the reaction of international stock markets to Fed policy shocks. The results of a study by Chen (2012), found that responses from the airline stock indexes, gambling, hotels and travel, and recreation to the shock component of the FFTR (Federal Fund Rate Target) were very significant. Therefore it is important to distinguish between

Mentari, N. M. I., \& Artini, L. G. S. (2019). Market reaction as an impact of announcement increase fed interest rate in Asian and European area. International Research Journal of Management, IT and Social Sciences, 6(5), $210-217$. https://doi.org/10.21744/irjmis.v6n5.728 
anticipated and unanticipated Fed policy actions. Failure to distinguish between the Fed's actions can lead to a significant bias in empirical estimation of the U.S. hospitality index reaction against changes in monetary policy. Based on several previous studies, the following hypothesis can be formulated:

H1: There is a difference in the average of abnormal returns around the date of the announcement of the increase FED interest rate on Asian and European Region stock indices.

\section{Materials and Methods}

The scope of this research is to examine the market reaction by looking at changes in stock price indexes around the date of the announcement of the Fed's interest rate increase in the Asian capital market and European regional capital markets. This is done because of the impact of the Fed's interest rate hike affects the global market.

The population in this study is the stock index in Asia and Europe. This research sample uses 18 stock indices from the Asian region and the European region. The research sample was selected using the Purposive Sampling method.

In this study, the process of collecting data is done by the method of non-participant observation. This is because the observations made are only observing and taking data that is already available on the stock exchanges of emerging markets in Asia and Europe as well as several other sites namely finance.yahoo.com and www.investing.com. Testing the research hypothesis using the One Way ANOVA analysis test which is part of the analysis of variance.

\section{Results and Discussions}

\subsection{Result}

\section{Test of Homogeneity of Variance}

In the Test of Homogeneity of Variance, Levene Statistics is used to check the homogeneity of variants whether all variants are the same. If the Sig. $>0.05$ then the same variant and hypothesis testing using Anova can be continued. If the Sig. $<0.05$ means the variance is not the same and the hypothesis test cannot be continued with Anova. This is done because one of the Anova test assumptions is the data has the same variant.

Table 1

Homogeneity testing result

\begin{tabular}{lllll}
\hline & Levene Statistic & df1 & df2 & Sig. \\
\hline AR BEFORE &, 364 & 1 & 16 &, 555 \\
AR AFTER & 1,382 & 1 & 16 &, 257 \\
\hline
\end{tabular}

Primary Data, 2019

Test of Homogeneity of Variances results indicates the value of Sig. before the announcement is $0.555>0.05$ this means that the average abnormal return data before the announcement in the two regions, Asia and Europe, has the same variant. The same results were also shown by the Test of Homogeneity of Variances after the announcement with Sig. 0.257> 0.05 which means that the average abnormal return data after the announcement has the same variance in both regions so that it can proceed to the Anova test stage.

Anova

ANOVA test aims to answer the hypothesis whether there are differences in the average abnormal return before and after the announcement of the Fed interest rate increase in Asia and Europe. 
Table 2

Anova Testing Result

\begin{tabular}{lllllll}
\hline & & $\begin{array}{l}\text { Sum of } \\
\text { Squares }\end{array}$ & df & Mean Square & F & Sig. \\
\hline AR BEFORE & Between Groups &, 000 & 1 &, 000 & 1,552 &, 231 \\
\cline { 2 - 7 } AR AFTER & Within Groups &, 000 & 16 &, 000 & & \\
& Total &, 000 & 17 & &, 010 &, 923 \\
& Between Groups &, 000 & 1 &, 000 & & \\
& Within Groups &, 000 & 16 &, 000 & & \\
& Total &, 000 & 17 & & & \\
\hline
\end{tabular}

Primary Data, 2019

In this study, the ANOVA test results showed the value of Sig. before the announcement is $0.231>0.05$ and the value after the announcement is Sig. is 0.923>0.05. The second value of Sig. > 0.05, which means that the test results reject the hypothesis (H1), so it can be concluded that there is no difference in the average abnormal return before and after the announcement of the Fed's interest rate increase in the Asian and European regions.

One-Sample T-Test

This study also tests the speed of market reaction by looking at how quickly the market reacts to the Fed interest rate hike in Asia and the European region. Market reaction speed testing is done using One-Sample T-Test. The speed of market reaction can be seen from the significant value of abnormal returns in each region per day so that it is known how many days are significant and not significant in each region.

Table 3

One-Sample T-Test

Abnormal Return Asia Area

\begin{tabular}{llll}
\hline Event Window & Average Abnormal Return & Sig. (2-tailed) & Description \\
\hline-10 & 0,00291 & 0,505 & Not. Sig. \\
-9 & $-0,00057$ & 0,869 & Not. Sig. \\
-8 & $-0,00103$ & 0,712 & Not. Sig. \\
-7 & $-0,00080$ & 0,826 & Not. Sig. \\
-6 & $-0,00589$ & 0,025 & Significant \\
-5 & $-0,00548$ & 0,013 & Significant \\
-4 & 0,00440 & 0,191 & Not. Sig. \\
-3 & 0,00051 & 0,813 & Not. Sig. \\
-2 & 0,00360 & 0,168 & Not. Sig. \\
-1 & 0,00607 & 0,063 & Not. Sig. \\
+1 & 0,00165 & 0,532 & Not. Sig. \\
+2 & 0,01054 & 0,004 & Significant \\
+3 & 0,00896 & 0,037 & Significant \\
+4 & 0,00384 & 0,205 & Not. Sig. \\
+5 & 0,00262 & 0,419 & Not. Sig. \\
+6 & 0,00360 & 0,162 & Not. Sig. \\
+7 & 0,00437 & 0,157 & Not. Sig. \\
+8 & $-0,00331$ & 0,192 & Not. Sig. \\
+9 & $-0,00221$ & 0,450 & Not. Sig. \\
+10 & 0,00431 & 0,041 & Significant \\
\hline
\end{tabular}

Primary Data, 2019

Mentari, N. M. I., \& Artini, L. G. S. (2019). Market reaction as an impact of announcement increase fed interest rate in Asian and European area. International Research Journal of Management, IT and Social Sciences, 6(5), $210-217$. https://doi.org/10.21744/irjmis.v6n5.728 
The results of the One Sample T-Test in Asia based on Table 3, in Asia, a significant abnormal return on the sixth day before the event $(-6)$, the fifth day before the event $(-5)$, the first day after the event $(+1)$, day the second after the event $(+2)$ and the ninth day after the event $(+9)$.

Table 4

One Sample T-Test

Abnormal Return Europe Area

\begin{tabular}{llll}
\hline Event Window & Average Abnormal Return & Sig. (2-tailed) & Description \\
\hline-10 & $-0,00301$ & 0,536 & Not. Sig. \\
-9 & $-0,01165$ & 0,096 & Not. Sig. \\
-8 & $-0,01106$ & 0,151 & Not. Sig. \\
-7 & $-0,00176$ & 0,773 & Not. Sig. \\
-6 & $-0,00080$ & 0,847 & Not. Sig. \\
-5 & $-0,00339$ & 0,161 & Not. Sig. \\
-4 & 0,01023 & 0,057 & Not. Sig. \\
-3 & 0,00381 & 0,384 & Not. Sig. \\
-2 & $-0,00053$ & 0,840 & Not. Sig. \\
-1 & 0,00070 & 0,858 & Not. Sig. \\
0 & $-0,00416$ & 0,516 & Not. Sig. \\
+1 & 0,01094 & 0,048 & Significant \\
+2 & 0,00773 & 0,208 & Not. Sig. \\
+3 & 0,00604 & 0,073 & Not. Sig. \\
+4 & $-0,00885$ & 0,048 & Significant \\
+5 & 0,00223 & 0,517 & Not. Sig. \\
+6 & $-0,00304$ & 0,244 & Not. Sig. \\
+7 & 0,00121 & 0,708 & Not. Sig. \\
+8 & 0,00188 & 0,583 & Not. Sig. \\
+9 & $-0,00123$ & 0,738 & Not. Sig. \\
+10 & 0,01024 & 0,100 & Not. Sig. \\
\hline
\end{tabular}

Primary Data, 2019

The results of the One-Sample T-Test in the European region as shown in Table 4 show that there are only a few days of abnormal returns of significant stock indices in the European region. Abnormal returns in the European region are only significant on the first day after the event $(+1)$ and the fourth day after the event $(+4)$.

The results of the one-sample t-test show that capital markets in Asia and Europe reacted quickly to announcements. This is shown by the results of the tests which tend to be insignificant in both regions. The insignificant test results show no abnormal return resulting from the Fed's interest rate announcement. The absence of abnormal returns indicates the market reacts quickly, that is information generated from announcements is quickly disseminated and reflected on stock prices. The results of this study are the same as those of Caporale et al., (2019), on the Ukrainian stock market that found no abnormal return around the day of the event. Overall, it seems that the stock market absorbs new information more quickly. Information that is absorbed quickly shows the market is in an efficient condition in the form of a half strong.

\subsection{Discussion}

Different test results using One Way Anova before the announcement of the Fed's interest rate hike in Asia and the European region showed insignificant results. The insignificant results showed that there were no differences in abnormal returns before and after the announcement of the Fed's interest rate hike in Asia and Europe.

The results of the same study were also found by Habib et al., (2015), who stated that the announcement of the credit rating did not have a significant impact on the return of abnormal shares of bank samples. Another study that has the same results found by Erer \& Erer (2017), found that interest rate decisions made by CBRT and FED had no significant effect on stock market volatility. This situation means that the expected interest rate decisions are valued by market participants and investors. 
The results of other studies that support the results of this study through univariate tests show that positive sovereign rating events do not cause significant bank stock price reactions, while negative events are associated with negative stock price effects on domestic banks (Hu, 2017).

Market reaction research as a result of the announcement of the Fed's interest rate increase is an event study aimed at examining market responses and abnormal returns. Empirically, the form of testing commonly used in event studies is whether there is an abnormal return or not around the date of the event. The results of this study are different from the theory which states that information arising from an event both corporate action or socioeconomic events can contain information that can affect stock prices in the capital market (Jones, 2014; Basak \& Khanna, 2017). The market reaction can occur if an announcement brings information content that is important to investors can cause changes in stock prices and cause abnormal returns.

The absence of differences in abnormal returns on the test results can mean the market does not react significantly. Not reacting significantly this means, there is a significant abnormal return on certain days $(-6,-5,+1,+2$ and +9$)$ alone in the Asian region for 20 days window period (event window). In the European region, there are also significant abnormal returns on certain days $(+1,+4)$ for 20 days window period (event window). Overall testing shows insignificant results because when viewed per day the number of significant days is less than the number of days that are not significant.

Based on the results of Pratiwi \& Wirakusuma (2018), the market reaction after the announcement of the Fed's March 22, 2018, interest rate increase did not show any difference in abnormal returns before and after the announcement of the Fed Fund Rate increase. In this research, there is no difference in the average abnormal return before and after the announcement of the Fed's interest rate hike in Asia and Europe due to several factors. First, the speed of market reaction in both regions. Based on the theory, if the market is efficient in the form of half strong then there is no investor or group of investors who can use the information published to obtain abnormal returns in the long term (Jogiyanto, 2017). The results of the study using one-sample t-test to see the speed of market reaction show that the capital markets in Asia and Europe are the same, namely efficient in the form of half strong.

Investors in both regions cannot use information from the announcement of the Fed's interest rate increase to obtain abnormal returns because the information is reflected very quickly into the stock price. One sample t-test test in Asia also showed a significant abnormal return on D-6 and D-5 before the announcement day not because of the announcement of the Fed's interest rate increase, but the side effects of the Chinese and American trade wars.

This condition can occur because the announcement of the Fed's interest rate increase on June 13, 2019, is not the first time made by the Fed. Since December 2015 the Fed has raised 7 times interest rates until June 2018. Therefore, investors have anticipated the Fed's rate hike event based on previous events and believe that the effects caused by the Fed's interest rate hike will not last long.

According to Jones (2014), one of the market requirements that can be said to be efficient is that all market participants can obtain information at the same time in a fairly cheap and easy way. On June 13, 2018, all market participants can obtain the same information because information regarding the announcement of the Fed's interest rate increase is widely available in the market. As information about the condition of the American economy is getting better will encourage the increase in interest rates The Fed is more quickly analyzed by investors for investment decisions.

The second factor is the uncertainty of the global economy and the effects of the trade war between China and America in addition to making the market a risk-off, the side effects of global economic uncertainty also make investors take the wait and see step. Investors are more careful and analyze what will happen in the future.

Investors are watching how countries and governments respond to the impact of the announcement of the Fed's interest rate hike. If investors see the state and the government is able to withstand the effects of the Fed's interest rate hike and the effects of the trade war so that economic fundamentals remain stable, this is seen by investors as a consideration to remain calm and not cause overreaction.

The third factor, the object of this study is the stock index in emerging market countries. The stock index is a statistical measure of changes in the price movement of a set of shares. Index movements represent part of the overall market movement. An increase in the Fed's interest rates may not affect all sectors, but an increase in the Fed's interest rates affects certain sectors such as the banking sector which will have a direct influence on interest rates. The stock prices of companies in different industries seem to react heterogeneously to interest rate announcements (Vithessonthia \& Techarongrojwong, 2013).

Mentari, N. M. I., \& Artini, L. G. S. (2019). Market reaction as an impact of announcement increase fed interest rate in Asian and European area. International Research Journal of Management, IT and Social Sciences, 6(5), 210-217. https://doi.org/10.21744/irjmis.v6n5.728 


\section{Conclusion}

The results found that there was no difference in the average abnormal return before and after the announcement of the Fed's interest rate hike, but on June 13, 2018, the global economic situation at that time was quite serious which was also caused by the impact of the Chinese and American trade wars. For investors, this research is expected to provide an illustration that an event will be interrelated that can affect globally. Therefore, in making investment decisions investors can see other events that may have an effect on other events so that the investment decisions made are right and the market is not only information efficient but the market can also be decision efficient.

\section{Research Limitations}

1) This research uses the main stock index as a sample so that the stock index under study is a stock index which consists of several sectors or all sectors in the capital market of each country, so the research does not specifically look at sectors related to events.

2) This event study research only examines market responses and abnormal returns. This research has not conducted theoretical testing as stated in the purpose of the event study. This theoretical testing is related to the event study theory which is associated with other relevant theoretical foundations.

\section{Conflict of interest statement}

The authors declared that they have no competing interest.

Statement of authorship

The authors have a responsibility for the conception and design of the study. The authors have approved the final article.

\section{Acknowledgments}

The authors would like to thank the editor of IRJMIS for their valuable time, support, and advice in completing the present research. 
References

Abdioğlu, N., \& Aytekin, S. (2016). The Role of Monetary Policy Announcements on Turkish Banks' Stock Returns. EMAJ: Emerging Markets Journal, 6(1), 63-69.

Aggarwal, R. (2017). Different avenues of capital market (secondary market) available for investing in market of yamuna nagar. International Research Journal of Management, IT and Social Sciences, 4(3), 34-50.

Basak, A., \& Khanna, K. (2017). A study on the selection criteria of different hotels of Delhi NCR in accordance to the hr policies and market trends. International Journal of Social Sciences and Humanities, 1(1), 27-38. https://doi.org/10.29332/ijssh.v1n1.13

Caporale, G. M., Plastun, O., \& Makarenko, I. (2019). Force majeure events and stock market reactions in Ukraine. Brunel University London, Economics and Finance Working Paper Series, (19-05). https://dx.doi.org/10.2139/ssrn.3362155

Chen, M. H. (2012). The reaction of US hospitality stock prices to Fed policy announcements. International Journal of Hospitality Management, 31(2), 395-398. https://doi.org/10.1016/j.ijhm.2011.06.014

Erer, E., \& Erer, D. (2017). Long memory in turkish stock market and effects of central banks'announcements. Financial Studies, 21(3).

Fausch, J., \& Sigonius, M. (2018). The impact of ECB monetary policy surprises on the German stock market. Journal of Macroeconomics, 55, 46-63. https://doi.org/10.1016/j.jmacro.2017.09.001

Ferguson, A., \& Lam, P. (2016). Government policy uncertainty and stock prices: The case of Australia's uranium industry. Energy Economics, 60, 97-111. https://doi.org/10.1016/j.eneco.2016.08.026

Grace, M. F., Rauch, J., \& Wende, S. (2017). The effect of monetary policy announcements and government interventions on the US insurance industry during the 2007-2009 crisis. The Journal of Risk Finance, 18(5), 500522. https://doi.org/10.1108/JRF-02-2017-0039

Gurgul, H., \& Wójtowicz, T. (2014). The impact of US macroeconomic news on the Polish stock market. Central European Journal of Operations Research, 22(4), 795-817. https://doi.org/10.1007/s10100-014-0343-x

Habib, Y., Nazir, M., Hashmi, S. H., \& Saeed, M. B. (2016). Credit rating announcements and stock returns: Evidence from the banking sector of Pakistan. Available at SSRN 2742879. https://dx.doi.org/10.2139/ssrn.2742879

$\mathrm{Hu}, \mathrm{H}$. (2017). The impact of sovereign rating events on bank stock returns: An empirical analysis for the Eurozone. The Journal of Risk Finance, 18(4), 338-367. https://doi.org/10.1108/JRF-12-2016-0156

Jogiyanto, H. (2017). Teori Portofolio dan Analisis Investasi, Edisi 11. Jogjakarta: BPFE-YOGYAKARTA.

Jones, C. P. (2014). Invesment (Principles and Concepts). Twelfth Edition. John Wiley \& Sons Singapore Pte.Ltd.

Kusuma, P. S. A. J., \& Yasa, G. W. (2019). Comparative analysis of company market reactions on right issue for pay debt and investment. International Research Journal of Management, IT and Social Sciences, 6(3), 29-36. https://doi.org/10.21744/irjmis.v6n3.626

Pratiwi, K.R.D.I \& Wirakusuma, I.G.M. (2018). Reaksi Pasar Modal Indonesia Atas Pengumuman Kenaikan Tingkat Suku Bunga Acuan Oleh Fed di AS. E-Jurnal Akuntansi Universitas Udayana, 25 (3), pp: 1966- 1993

Tandelilin, E. (2010). Portofolio dan Investasi, Edisi Pertama. Yogyakarta: Kanisius, 1(1).

Tsai, B. H., \& Chen, P. J. (2018). Market Reactions to Oil Price Changes in the Taiwan's Transportation Industry. International Journal of Business and Information.

Vithessonthi, C., \& Techarongrojwong, Y. (2013). Do monetary policy announcements affect stock prices in emerging market countries? The case of Thailand. Journal of Multinational Financial Management, 23(5), 446-469. https://doi.org/10.1016/j.mulfin.2013.10.001

Wang, J., \& Zhu, X. (2013). The reaction of international stock markets to Federal Reserve policy. Financial Markets and Portfolio Management, 27(1), 1-30. https://doi.org/10.1007/s11408-012-0204-3

Wardhani, L. S. (2012). Reaksi Pasar Modal Indonesia Terhadap Peristiwa Pemilihan Gubernur DKI Jakarta Putaran II 2012. Jurnal ilmiah mahasiswa Fakultas Ekonomi dan Bisnis Universitas Brawijaya, 1(1).

Young, M., \& Bacon, F. (2012). The federal open market committee and the federal funds rate: A test of market efficiency. Academy of Banking Studies Journal, 11(2), 81.

Mentari, N. M. I., \& Artini, L. G. S. (2019). Market reaction as an impact of announcement increase fed interest rate in Asian and European area. International Research Journal of Management, IT and Social Sciences, 6(5), $210-217$. https://doi.org/10.21744/irjmis.v6n5.728 